\title{
Yeni Mezun Hemşirelerde İşe Hazır Olma Ölçeği’nin Türkçe’ye Uyarlanması: Geçerlik ve Güvenirlik
}

\author{
Turkish Adaptation of The Work Readiness Scale for Graduated Nurses: Validity and Reliability
}

\author{
Ayşe YILDIZ KESKIN ${ }^{1}$, Manar ASLAN ${ }^{2}$
}

\section{ÖZ}

Bu araştırma, Yeni Mezun Hemşirelerde İșe Hazır Olma Ölçeği'ni Türkçe' ye uyarlamak, geçerlik ve güvenirliğini belirlemek amacıyla yapılan metodolojik tipte bir çalışmadır. Araştırma Konya'da bulunan hastanelerde çalışan ve meslekte $0-3$ yıl arası görev yapan hemşirelerden gönüllülük esasına dayanarak 380 kişiyle yapılmıştır. Araştırmanın verileri Mart 2017-Haziran 2017 tarihleri arasında toplanmıştır. İşe Hazır Olma Ölçeği 46 madde ve dört alt boyuttan (İş yeterliliği, sosyal zekâ, örgütsel farkındalık, kişisel çalışma özellikleri) oluşan 10'lu likert tipi bir ölçektir. Ölçeğin toplamının cronbach alfa güvenirlik katsayısı tüm ölçek için .94 bulunmuştur. Ölçek maddelerinin madde-toplam puan korelasyon katsayıları .28 - .73 arasında olduğu belirlenmiştir. Ölçeğin zamana bağlı değişkenliği için yapılan test-tekrar test analizi sonucunda her iki uygulamaya ilişkin korelasyon katsayısı .83 ile .94 arasındadır. Ölçeğin yap1 geçerliğini test etmek için doğrulayıcı faktör analizi yapılmıştır. Ölçek orijinali gibi dört alt boyuttan oluşmaktadır. Yeni Mezun Hemşirelerde İşe Hazır Olma Ölçeği'nin Türkçe formunun geçerli ve güvenilir olduğu belirlenmiştir.

Anahtar Kelimeler: İşe Hazır Olma, Yeni Mezun Hemşire, Geçerlik, Güvenirlik, Ölçek.

\begin{abstract}
This research is a methodological type study designed to adapt the Work Readiness Scale in new graduated nurses to Turkish and to determine its validity and reliability in nursing. The research was applied to 380 nurses working in the hospitals and nurses employed for 0-3 years in profession. The data of the study were collected between March 2017-June 2017. The Work Readiness Scale is a 10-point likerttype scale consisting of 46 items and four subdimensions (work competence, social intelligence, organizational awareness and personal work characteristics). The cronbach alpha reliability coefficient of the scale total was .94 for the whole scale. The item-total score correlation coefficients of the scales were determined to be between $.28-.73$. As a result of the test-retest analysis for time - dependent variability of the scale, the correlation coefficient for both applications is between .83 and .94 . Confirmatory factor analysis was performed to test the validity of the scale. The scale consists of four subdimensions like the original. It has been determined that the Turkish form of the Work Readiness Scale in New Graduated Nurses is valid and reliable.
\end{abstract}

Keywords: The Work Readiness, New Graduated Nurse, Validity, Reliability, Scale.

\footnotetext{
Bu makale Necmettin Erbakan Üniversitesi, Sağllk Bilimleri Enstitüsü’nde yapılan 'Yeni Mezun Hemşirelerde İşe Hazır Olma Ölçeğinin Geçerliği ve Güvenirliği’ başlıklı tezden hazırlanmıştır.

${ }^{1}$ Ayşe YILDIZ KESKİN, Öğr. Gör, Hemşirelikte Yönetim, Mersin Üniversitesi, ayseyildiz87@hotmail.com, ORCID:0000-0002-0920-8030 ${ }^{2}$ Manar ASLAN, Dr. Öğr. Üyesi, Hemşirelikte Yönetim, Trakya Üniversitesi, Hemşirelik Bölümü, manaraslan@hotmail.com, ORCID:00000003-0932-5816 


\section{GİRIŞ}

Gelişen teknoloji ile birlikte yeni hastalıkların ortaya çıkması, bakım gereksinimlerinin değişmesi ve insanların gün geçtikçe artan oranlarda kaliteli hemşirelik bakımını talep etmesi gibi nedenler sağlık bakım sistemi içinde değişime açık, motivasyonu yüksek ve profesyonel nitelikleri gelişmiş hemşirelere duyulan gereksinimleri ve beklentileri giderek arttırmaktadır. ${ }^{1-3}$

Yeni mezunlar hemşire yetersizliğinin fazla olduğu, ileri tıbbi teknoloji, yüksek hasta potansiyeli ve kit kaynaklar ile karakterize karışık bir çalışma alanında işe başlamaktadırlar. ${ }^{4} \mathrm{Bu}$ durum tüm dünyada hemşire açı̆̆ının artmasına zemin hazırlamakta ve hemşirelerin işlerine hazır olmamaları da bu sorunu tetiklemektedir. İşe hazır olma, mezunların çalışma ortamında onları mesleğe hazır hale getiren ve başarılı olmasını sağlayan tutum ve niteliklere sahip oldukları bir ölçü olarak tanımlanabilir. ${ }^{5,6}$ Ayrıca mezunların öğrenme, iş bulma, işe alım ve potansiyelini belirlemek için göz ardı edilmeyecek bir seçim kriteridir ve gittikçe önem kazanmaktadır. ${ }^{6-9} \mathrm{Bu}$ sadece bir dizi klinik beceriye sahip olmaktan daha fazlasıdır ve bir kişinin bir organizasyonda başarıyla işlev görmesine olanak tanıyan yeteneğe ve özelliklere sahip olmasıdır. İşe hazır olmak konusunda dört tane temel alt boyut bulunmaktadır, bunlar; sosyal zeka, örgütsel farkındalık, iş yeterliliği ve kişisel çalışma özellikleridir. ${ }^{5}$

Günümüzdeki hemşire azlığı ve hemşirelik işgücünün yaşlanması göz önüne alındığında, yeni hemşirelerin istihdamı ve elde tutulması yüksek bir öncelik haline gelmektedir. Bununla birlikte, yeni mezun hemşirelerin işgücüne geçiş sürecindeki deneyimleri, gerçeklik şoku ${ }^{10}$ veya destekleyici olmayan çalışma ortamlarının sonucu olarak geçiş şoku ${ }^{11}$ olarak tanımlanmaktadır. $\mathrm{Bu}$ koşullar, yeni hemşirelerin önemli ölçüde yıpranmasına ve meslekten uzaklaşmasina neden olabilmektedir. Dinamik sağlık ortamı, zaman yönetimi, klinik becerilerle ilgili deneyimsizlik, sağlık ekibinin diğer üyeleriyle iletișim kurmadaki güçlükler ve artan hasta iş yükünün yönetimi, yeni mezun hemşirelerin işe hazır olma durumunu olumsuz etkilemektedir. ${ }^{12-15}$

Yeni mezun hemşireler hemşireliğe geçişte karmaşık ve stresli bir durumla karşılaştığı için hemşirelik uygulamaları bağlamında sosyalleşmekle kalmamalı, hasta bakımından sorumlu olabilmeli, aynı zamanda davranışlarını şekillendiren çeşitli resmi ve gayri resmi kuralları ve düzenlemeleri öğrenmelidirler. ${ }^{16} \mathrm{Bu}$ geçiş döneminde yeni nitelikli hemşirelere yardım etmek ve ortaya çıkan sorunlarla başa çıkmak için, sağlık kuruluşları ve eğitim kurumları, program tanıtımı ve atölyeler gibi çeşitli eğitim stratejileri sunmalı, hepsinden önemlisi geliştirmeye okul döneminde başlamalıdır. ${ }^{17}$

Türkiye de yeni mezun hemşirelerde işe hazır olma ve işe hazır oluşluk durumunun hiç çalışılmamış olması nedeniyle bu çalışmada, işe hazır olma ölçeğinin geçerlik ve güvenirlik çalışması yapılarak Türk toplumunda kullanılıp kullanılamayacağının belirlenmesi amaçlanmıştır.

\section{MATERYAL VE METOT}

$\mathrm{Bu}$ araştırma "Yeni Mezun Hemşirelerde İşe Hazır Olma Ölçeği”ni Türkçe'ye uyarlamak, geçerlik ve güvenirliğini değerlendirmek amacı ile yapılmış metodolojik türde bir araştırmadır.

Araştırmanın evrenini; ilde bulunan tıp fakülteleri ve il sağlik müdürlüğüne bağl1 tüm hastanelerde bulunan 0-3 yıldır çalışan 520 hemşire oluşturmuştur. Scott'un (2005) çalışmasında belirtildiği üzere Benner (1984), bir işte yeterli düzeye gelebilmenin ancak ilk üç yılda gerçekleşebileceğini ileri sürmektedir. ${ }^{18} \mathrm{Bu}$ nedenle çalışma yılı en fazla 3 yıl olan hemşireler araştırmanın evrenini oluşturmuştur. Örneklemi ise iki tıp 
fakültesi hastanesinde ve İl Sağllk Müdürlüğü'ne bağlı hastanelerden ildeki dört ve ilçelerdeki on beş hastanede, hemşirelik mesleğinde 0-3 yıl çalışmış olan 380 hemşire oluşturmuştur.

Faktör analizinde örneklem büyüklüğünün hesaplanmasında ölçek madde sayısının en az 5-10 kat1 olması önerilmektedir. ${ }^{19-21}$ Örnekleme ölçeğin madde sayısının on katı (460) oranında hemşire alınması planlanmış fakat 0-3 yıl arası çalışan hemşire sayısının toplamda 520 kişi olması, araştırmanın yapıldı ̆̆ zaman izinli olanlar ve araştırmaya katılmayı kabul etmeyenler sebebiyle toplam 380 kişiye ulaşılmıştır. Bu sayı ölçek madde sayısının sekiz katından biraz fazladır $(46 \times 8=368)$.

Verilerin toplanmasında aşağıdaki araçlar kullanılmıştır:

\section{Sosyo Demografik ve Çalışma} Özellikleri: Araştırmacı tarafindan oluşturulan formda; yaş, cinsiyet, medeni durum, eğitim durumu, meslekte çalışma süresi, kendinizi işinize ne kadar hazır hissediyorsunuz gibi sorular yer almaktadir.

\section{Mezun Hemşirelerde İşe Hazır Olma Ölçeği (The Work Readiness Scale-} Graduate Nurses): Bu ölçek ilk olarak Caballero ve ark. tarafindan genel olarak mezunların işe hazır oluşlarını ölçmek amaciyla 64 madde olarak oluşturulmuştur. ${ }^{22}$ Sonrasında hemşireler için ölçeğin uyarlanmasına karar verilmiş ve Walker ve ark. ${ }^{6}$ tarafından 46 soruya indirilmiştir. Dört boyuttan oluşan ölçek 0-3 yıl arası çalışan 450 hemsireye uygulanmıs ve cronbach alfa değeri .92 bulunmuştur. Ölçekte yer alan ifadeler; 1 tamamen katılmiyorum, 10 tamamen katılıyorum olarak puanlanmaktadır ve $10^{\prime}$ lu likert tipi bir ölçektir. Ölçekten alınan en düşük puan 46 , en yüksek puan ise 460'tır. Ölçek dört alt boyuttan oluşmaktadır;

İş Yeterliliği Alt Boyutu: İş yeterlilik boyutunu belirleyen toplam 14 maddeyi (114. sorular) içerir. Hemşireler her zaman topluma profesyonel olarak nasıl katkıda bulunabilecekleri konusunda zorluklar yaşamaktadırlar. Sürekli olarak doğrudan bakım sağlama, bireysel yaşamları koruma ve günlük yaşam aktivitelerini sürdürmeye yönelik, yeni mezun hemşirelerin sorumluluk almaları beklenmektedir. Bunu bașarabilmeleri için yeni mezun hemșirelerin yeterliliklerini geliştirmeleri ve günlük uygulamalarında bunu kullanmaları önemlidir. ${ }^{23}$

Sosyal Zeka Alt Boyutu: Sosyal zeka boyutunu belirleyen toplam 8 maddeyi (1522. sorular) içerir. Thorndike (1920) sosyal zekayı, diğer bireyleri anlama yeteneği olarak tanımlamıștır. ${ }^{24}$ Hastalar, aile üyeleri ve personeller ile farklı etkileşimler gerçekleştirmek, hemşirelerin profesyonel rolünün önemli bir bileşenidir. $\mathrm{Bu}$ nedenle, sosyal zeka yönü güçlü olan yeni mezun hemşirelerin, hem işe alışma konusunda yumuşak bir geçiş yaşayabilecekleri, hem de akranlarından daha fazla çalışmaya hazır olabilecekleri düşünülebilir.

\section{Örgütsel Farkındalık Alt Boyutu:} Örgütsel farkındalık boyutunu belirleyen 16maddeyi (23-38. sorular) içerir. Örgütler, bir amaca hizmet etmek ve hedeflere ulaşmak için bilinçli olarak yapılandırılmış ve koordine edilen sosyal sistemlerdir. ${ }^{25}$ Örgütsel farkındalık faktörü de olgunluk ve profesyonel gelişim özelliklerini içerir. Örgütsel farkındalık hizmet ve hastane usul/prosedürleri hakkında bilgi sahibi olmay1, olgun olabilmeyi ve profesyonel gelişimi gerektirir. ${ }^{5}$

\section{Kișisel Çalıșma Özellikleri Alt Boyutu:} Kişisel çalışma özellikleri boyutunu belirleyen 8 maddeyi (39-46.sorular) içerir. Hemșirelerin mesleklerinde başarılı olabilmeleri için aşağıdaki kişisel özelliklere sahip olması gerektiği vurgulanmaktadır. Bunlar: iletişim ve kişisel beceriler, empati ve merhamet, gerçekçi ve esneklik, dürüstlük ve güvenilirlik, zaman yönetimi becerisidir. ${ }^{26}$ Yeni mezun hemşirelerin yetkin kişisel çalışma özelliklerini gösterme yeteneği, stresi yönetmek ve sağlıklı bir iş hayatı dengesini sürdürmek için gerekli olabilir.

Walker ölçeğin alt boyutlarının Cronbach alfa değerlerini; iş yeterliliği alt boyutu için .88 , sosyal zeka alt boyutu için .87 , örgütsel farkındalık alt boyutu için .85 , kişisel çalıșma özellikleri alt boyutu için .84, olarak 
belirlemiştir. ${ }^{6}$ Ölçekten alınan puan arttıkça hemşirelerin işe hazır olma düzeyleri de artmaktadir.

Veriler Mart-Haziran 2017 tarihleri arasında araştırmacı tarafından hemşirelerden alınan bireysel onamlar sonucunda toplanmıştır. Formu dolduranlara çalışmanın amacıyla ilgili bilgi verilmiştir ve formlar mesai saatleri içerisinde (08:00-17:00) toplanmıştır.

\section{Araştırmanın Etik Yönü}

Yeni Mezun Hemşirelerde İşe Hazır Olma Ölçeği (The Work Readiness Scale-Graduate Nurses)'nin Türkçe'ye uyarlanabilmesi için Dr. Arlene Walker'dan e-mail yoluyla gerekli izinler alınmıştır. Araştırmanın yürütülebilmesi için etik kurul onayı (Tarih: 31.05.2016 Sayı: 2305) ve kurumlardan izin (Tarih: 04.11.2016 Say1: 21347889/799; Tarih: 02.03.2017 Say1: E-5298; Tarih: 21.03.2017 Say1:145 67952-100-E3674) alınmıştır. Araştırma kapsamındaki hemşirelere ölçek uygulamasından önce araştırmanın amacı hakkında açıklamalarda bulunulup, katılımları için bireysel onamları sözel olarak alınmıştır.

Çalışmada istatistiksel anlamlılık düzeyi $\mathrm{p}<.05$ olarak kabul edilmiştir. Araştırmada veri toplama araçları ile elde edilen veriler "SPSS 21.0" istatistik paket programı yardımıyla analiz edilmiştir. Katılımcıların tanımlayıcı özellikleri ve ölçek puanlarının tanımlayıcı istatistikleri için sayı, yüzde, ortalama, standart sapma ve aritmetik ortalama; dil geçerliği için İngilizce'den Türkçe'ye ve Türkçe'den İngilizce'ye çeviri, Türkçe ve İngilizce form puanlarının karşılaştırılmasında bağımlı gruplarda t testi ve tutarlılığın incelenmesinde Pearson korelasyon analizi; kapsam geçerliği için uzman görüşü (kapsam geçerlik indeksi); yap1 geçerliği için doğrulayıcı faktör analizi; ölçüt geçerliği için Pearson korelasyon analizi kullanılmıştır. Güvenirlik analizlerinden ise Pearson korelasyon, Cronbach alfa, test -tekrar test puanlarının karşılaştırılmasında bağımlı gruplarda t-testi kullanılmıştır.

\section{BULGULAR VE TARTIŞMA}

Çalışmada sosyo-demografik özellikler incelendiğinde; katılımcıların \%68.2'sinin kadın, \%66.6'sının bekar, \%51.8'inin lisans mezunu, \%56.6'sının meslekte çalışma süresinin 2 yıldan fazla, yaş ortalamasının $24.14 \pm 2.57$ olduğu ve 'Kendinizi işinize ne kadar hazır hissediyorsunuz?' sorusunun ortalamasının $\quad 7.64 \pm 2.10 \quad$ olduğu belirlenmiştir (Tablo 1).

Ölçeğin maddelerinin ve alt boyutlarının olası ve alınan en düşük/en yüksek puan, her bir alt boyutun puan ortalamas1, madde ortalamaları ve standart sapmaları Tablo 2'de verilmiştir. Ölçeğin toplam puan ortalaması $364.77 \pm 51.89$ olarak bulunmuştur. Alt boyutlardan örgütsel farkındalı (135.47 \pm 19.81$)$ alt boyutu en yüksek madde ortalamasina (8.46) sahiptir.
Tablo 1. Hemşirelerin Tanımlayıcı Özelliklerine Göre Dağılımı (n: 380)

\begin{tabular}{|c|c|c|}
\hline Değişkenler & Sayı & $\%$ \\
\hline \multicolumn{3}{|l|}{ Cinsiyet } \\
\hline Erkek & 121 & 31,8 \\
\hline Kadın & 259 & 68,2 \\
\hline \multicolumn{3}{|l|}{ Medeni durum } \\
\hline Evli & 127 & 33,4 \\
\hline Bekar & 253 & 66,6 \\
\hline \multicolumn{3}{|l|}{ Eğitim düzevi } \\
\hline SML & 138 & 36,3 \\
\hline Ön lisans & 36 & 9,5 \\
\hline Lisans & 197 & 51,8 \\
\hline Lisansüstü & 9 & 2,4 \\
\hline \multicolumn{3}{|l|}{ Calıșma süresi } \\
\hline$\leq 1 \mathrm{y} 1 \mathrm{l}$ & 50 & 13,2 \\
\hline $1,1-2 \mathrm{y} 11$ & 115 & 30,3 \\
\hline \multirow[t]{2}{*}{$2>x>3 y 1$} & 215 & 56,6 \\
\hline & Min-Max & $x^{-} \pm \mathrm{SS}$ \\
\hline Yaş & $19-30$ & $24,14 \pm 2,57$ \\
\hline $\begin{array}{l}\text { Meslekte } \\
\text { süresi (yıl) }\end{array}$ & $0,08-3$ & $2,34 \pm, 78$ \\
\hline $\begin{array}{l}\text { Kendinizi işinize ne } \\
\text { kadar hazır } \\
\text { hissediyorsunuz? }\end{array}$ & $1-10$ & $7,64 \pm 2,10$ \\
\hline
\end{tabular}


Tablo 2. Yeni Hemşirelerin Mezun Hemşirelerde İşe Hazır Olma Ölçeği ve Alt Boyutlarından Aldıkları Puanların Tanımlayıcı İstatistikleri (n: 380)

\begin{tabular}{|c|c|c|c|c|}
\hline $\begin{array}{l}\text { Ölçek ve alt } \\
\text { boyutlar }\end{array}$ & $\begin{array}{l}\text { Olası } \\
\text { min- } \\
\text { max } \\
\text { puan }\end{array}$ & $\begin{array}{l}\text { Alınan } \\
\text { min- } \\
\text { max } \\
\text { puan }\end{array}$ & $x^{-} \pm$SS & $\begin{array}{c}\text { Madde } \\
\text { ortalam } \\
\text { ası }\end{array}$ \\
\hline Ölçek genel & $\begin{array}{l}46- \\
460\end{array}$ & $\begin{array}{c}154- \\
460\end{array}$ & $\begin{array}{l}364,77 \\
\pm 51.89\end{array}$ & 7,92 \\
\hline İş yeterliliği & $\begin{array}{l}14- \\
140\end{array}$ & $21-140$ & $\begin{array}{r}109,34 \\
\pm 19,52 \\
\end{array}$ & 8,01 \\
\hline Sosyal zeka & $8-80$ & $8-80$ & $\begin{array}{c}64,12 \pm \\
12,35\end{array}$ & 8,01 \\
\hline $\begin{array}{l}\text { Örgütsel } \\
\text { farkındalık }\end{array}$ & $\begin{array}{l}16- \\
160\end{array}$ & $30-160$ & $\begin{array}{l}135,47 \\
\pm 19,81\end{array}$ & 8,46 \\
\hline $\begin{array}{l}\text { Kişisel } \\
\text { çalışma } \\
\text { özellikleri }\end{array}$ & $8-80$ & $12-80$ & $\begin{array}{c}55,84 \pm \\
16,90\end{array}$ & 6,98 \\
\hline
\end{tabular}

\section{Yeni Mezun Hemşirelerde İşe Hazır Olma Ölçeği'nin Geçerlik Bulguları}

Ölçeğin Türkçeye çevrilen formu ve İngilizce formu her iki dili iyi bilen tıp ve hemşirelik mezunu olan çoğunluğu idari birimlerde çalışan 30 kişiye iki hafta ara ile tekrarlanarak uygulanmış, elde puan ortalamaları arasındaki fark bağımlı gruplarda $\mathrm{t}$ testi ile karşılaştırılmış ve sonuçlar arasındaki tutarlılık Pearson korelasyon analizi ile incelenmiştir.

Ölçeğin Türkçe ve İngilizce ifadelerini aynı şekilde algılayıp algılamadıkları (ya da anlayıp anlamadıklarını) belirlemek amacıyla aynı gruba iki hafta ara ile uygulanan ölçeğin Türkçe ve İngilizce formundan elde edilen toplam puan ve iş yeterliği, örgütsel farkındalık, sosyal zeka ve kişisel çalışma özellikleri olan dört alt boyutunun puan ortalamaları arasında anlamlı düzeyde fark olmadığ1 saptanmıştır (p>.05, Tablo 3). Ölçeğin ve dört alt boyutunun Türkçe ve İngilizce formundan elde edilen puanları arasında pozitif yönde, çok güçlü ve istatistiksel olarak ileri düzeyde anlamlı bir ilişki olduğu belirlenmiştir ( $\mathrm{r}=.86$ ile .92 aras1, $\mathrm{p}<.001$, Tablo 3).

Tablo 3. Yeni Mezun Hemşirelerde İşe Hazır Olma Ölçeği’nin İngilizce ve Türkçe Formunun Puan Ortalamalarının Karşılaştırılması (n: 30)

\begin{tabular}{|c|c|c|c|c|c|c|c|}
\hline \multicolumn{2}{|c|}{ Ölçek ve Alt boyutları } & $\begin{array}{c}\text { İngilizce } \\
\text { Formu } \\
\overline{\mathbf{x}}_{ \pm} \mathbf{S S}\end{array}$ & $\begin{array}{c}\text { Türkçe Formu } \\
\overline{\mathbf{x}}_{ \pm S S S}\end{array}$ & $\mathbf{t}^{*}$ & $\mathbf{p}$ & $\mathbf{r}^{* *}$ & $\mathbf{p}$ \\
\hline \multicolumn{2}{|c|}{$\begin{array}{l}\text { Yeni Mezun } \\
\text { Hemşirelerde İşe } \\
\text { Hazır Olma Ölçeği } \\
\text { Toplam Puanı }\end{array}$} & $380,27 \pm 33,69$ & $375,83 \pm 33,45$ & 1,561 &, 129 &, 89 &, 000 \\
\hline \multirow{4}{*}{ 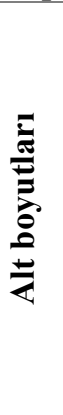 } & 1.İş yeterliliği & $111,47 \pm 12,86$ & $109,83 \pm 12,70$ & 1,702 & ,099 & ,92 &, 000 \\
\hline & 2.Sosyal zeka & $67,47 \pm 8,95$ & $65,93 \pm 8,87$ & 1,936 &, 063 &, 88 &, 000 \\
\hline & $\begin{array}{l}\text { 3.Örgütsel } \\
\text { farkındalık }\end{array}$ & $142,50 \pm 11,31$ & $142,53 \pm 11,06$ & ,039 & ,969 & ,91 &, 000 \\
\hline & $\begin{array}{l}\text { 4.Kişisel } \\
\text { çalışma } \\
\text { özellikleri }\end{array}$ & $58,83 \pm 14,37$ & $57,53 \pm 13,36$ & ,959 & ,346 &, 86 &, 000 \\
\hline
\end{tabular}

** r: Pearson korelasyon analizi

Ölçeğin Türkçe formunun kapsam geçerliği için ölçek maddelerinin uygunluğu konusunda hemşirelikte yönetim ve araştırma dersi veren ölçek geliştirme konusunda uzman dokuz hemşire öğretim üyesinin görüşü alınmıştır. Uzmanlardan maddelerin uygunluğunu 1-4 puan arasında değerlendirmeleri istenmiş ve ölçeğin kapsam geçerlik indeksi değerinin 0,95 olduğu bulunmuştur.

Ölçeğin Türkçe formunun yapı geçerliği için yapılan doğrulayıcı faktör analizinde (DFA) uyum değerleri Tablo 4'te verilmiştir. Ölçek maddelerinin kendi boyutu ile olan yol 
katsayıları (faktör yükleri) iş yeterliliği alt boyutunda .35 ile .82, sosyal zeka alt boyutunda .68 ile .84 , örgütsel farkındalık alt boyutunda .53 ile .89 , kişisel çalışma özellikleri alt boyutunda .61 ile .75 arasinda olduğu bulunmuştur (Şekil 1).

Tablo 4. Yeni Mezun Hemşirelerde İşe Hazır Olma Ölçeğinin Doğrulayıcı Faktör Analizi Uyumluluk Değerleri (n:380)

\begin{tabular}{|c|c|}
\hline $\begin{array}{l}\text { DFA uyumluluk } \\
\text { istatistiği }\end{array}$ & DFA uyum değerleri \\
\hline Ki-kare / p değeri & $3772,97 / 0,000(\mathrm{p}<.05)$ \\
\hline $\begin{array}{ll}\text { Ki-kare: } & \text { serbestlik } \\
\text { derecesi } & \end{array}$ & $3772,97: 979=3,85$ \\
\hline RMSEA / p & $.087(\mathrm{p}<.05)$ \\
\hline SRMR & .064 \\
\hline CFI & .97 \\
\hline NNFI & .97 \\
\hline GFI & .70 \\
\hline AGFI & .67 \\
\hline
\end{tabular}

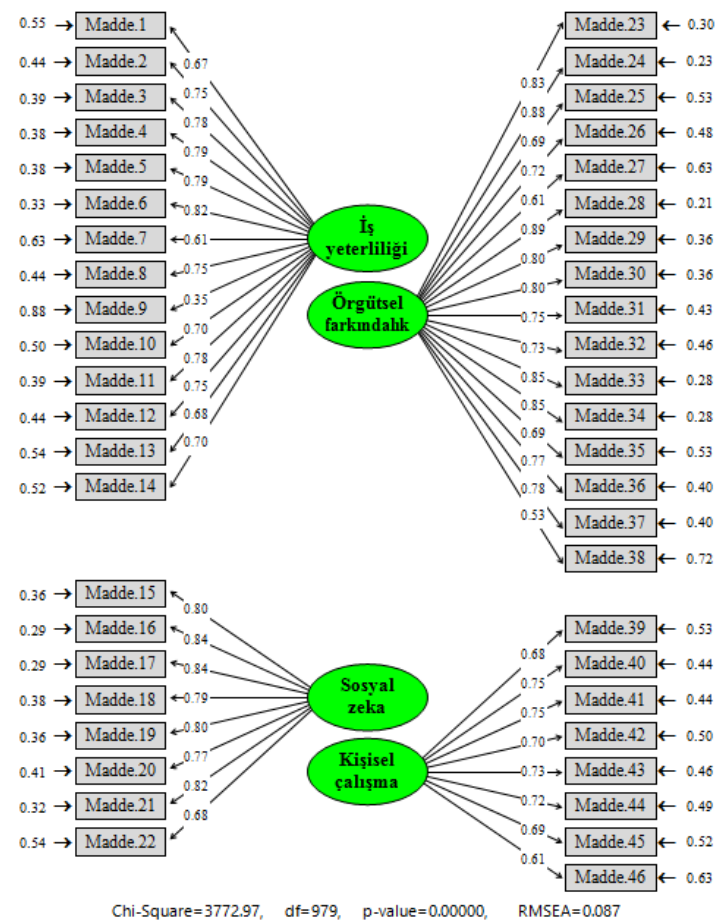

Sekil 1. Yeni Mezun Hemșirelerde İșe Hazır Olma Ölçeğinin Doğrulayıcı Faktör Analizi: Yol Katsayıları ve Hata Varyansları
Ölçeğin Türkçe Formunun yap1 geçerliğini değerlendirmek için eşzamanlı ölçüt geçerliği olarak hemşirelerin "Kendinizi işinize ne kadar hazır hissediyorsunuz." sorusuna (1-10 puan aras1) verdikleri puanlar ile ölçekten aldıkları puanların uyumu Pearson korelasyon analizi ile test edilmiştir.

Hemşirelerin yeni mezun hemşirelerde işe hazır olma ölçeğinden aldıkları puanlar ile eş zamanlı kullanılarak elde edilen "kendinizi işinize ne kadar hazır hissediyorsunuz" sorusundan elde edilen puanlar arasinda pozitif yönde, güçlü ve istatistiksel olarak ileri düzeyde anlamlı bir ilişkinin olduğu belirlenmiştir $(r=.61, p=.000$, Şekil 2).

\section{Yeni Mezun Hemşirelerde İşe Hazır Olma Ölçeği'nin Güvenirlik Bulguları}

Ölçeğin alt boyutlarının toplam ölçek puanıla korelasyonları incelendiğinde, güvenirlik katsayılarının iş yeterliği alt boyutunda $\mathrm{r}=.85$, sosyal zeka alt boyutunda $\mathrm{r}=.83$, ve örgütsel farkındalık alt boyutunda $\mathrm{r}=.81$ ile çok güçlü düzeyde, kișisel çalıșma özellikleri alt boyutunda $r=.54$ ile güçlü düzeyde olmak üzere pozitif yönde ve istatistiksel olarak ileri düzeyde anlamlı olduğu saptanmıştır ( $\mathrm{p}<.001$, Tablo 5).

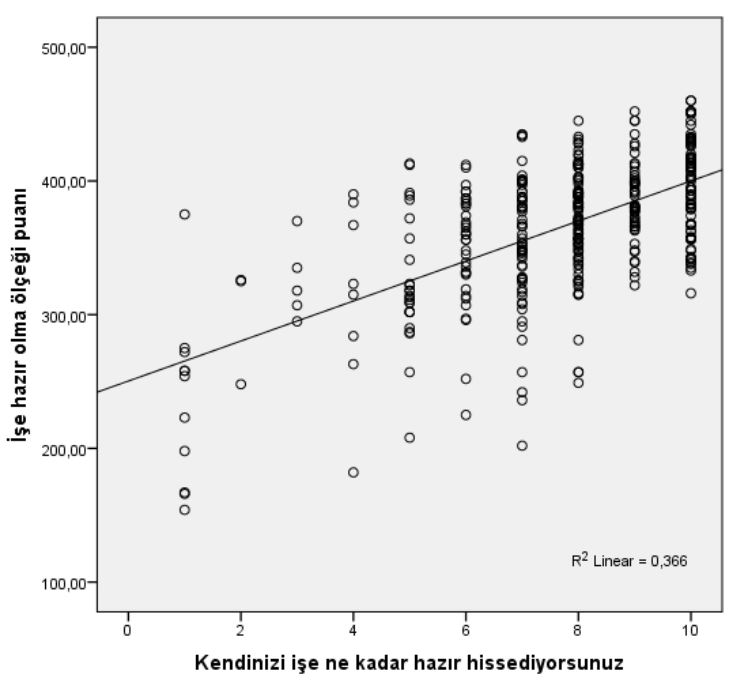

Şekil 2. İşe Hazır Olma Ölçeği ile Kendini İşe Hazır Hissetme Puanlarının İlişkisi

Ölçeğin ve alt boyutlarının güvenirlik göstergelerinden biri olan iç tutarlılığı test etmek için yapılan analizde Cronbach alfa güvenirlik katsayısı tüm ölçek için $\alpha=.94$ bulunmuştur. Ölçeğin alt boyutlarının 
Cronbach alfa güvenirlik katsayısı; iş yeterliği ve sosyal zeka alt boyutunda .91, örgütsel farkındalık alt boyutunda .93 , kişisel çalışma özellikleri alt boyutunda .88 olarak bulunmuştur.

Ölçeğin zamana göre değişmezliği çalışmaya katılan ilk 50 hemşireye ilk test uygulamasindan sonra iki hafta ara ile yapılan ikinci ölçümden elde edilen ölçek ve dört alt boyutunun puan ortalamaları arasındaki fark bağımlı gruplarda t testi ( $=\mathrm{iki}$ eş arasındaki farkın önemlilik testi) ile değerlendirilmiştir. Hem toplam ölçeğin hem de dört alt boyutun tekrarlayan iki ölçümden elde edilen puan ortalamasi arasinda anlaml düzeyde fark olmadığı saptanmıştır ( $\mathrm{p}>.05$, Tablo 5).

Ölçeğin ve dört alt boyutunun test-tekrar test puanları arasındaki ilişki Pearson korelasyon analizi ile incelendiğinde; hem toplam ölçek, hem de dört alt boyutun ilk ve ikinci ölçümden elde edilen puanları arasında çok güçlü $(r=.83$ ile .94 arasında), pozitif yönde ve istatistiksel olarak ileri düzeyde anlamlı bir ilişki olduğu saptanmıştır (p<.001, Tablo 5).

Tablo 5. Yeni Mezun Hemşirelerde İşe Hazır Olma Ölçeği ve Alt Boyutlarının Test-Tekrar Test Puan Ortalamalarının Karşılaştırılması ve Korelasyonları (n: 50)

\begin{tabular}{|c|c|c|c|c|c|c|}
\hline $\begin{array}{c}\text { Ölçek ve } \\
\text { Alt Boyutları }\end{array}$ & $\begin{array}{c}\text { İlk Uygulama } \\
\overline{\overline{\mathbf{x}}}_{ \pm \mathrm{SS}}\end{array}$ & $\begin{array}{c}\text { İkinci Uygulama } \\
\overline{\mathbf{x}} \pm \mathbf{S S}\end{array}$ & $\mathbf{t}^{*}$ & $\mathbf{p}$ & $\mathbf{r}^{* *}$ & $\mathbf{p}$ \\
\hline $\begin{array}{l}\text { Ölçek Toplam } \\
\text { Puanı }\end{array}$ & $370,80 \pm 47,85$ & $375,52 \pm 51,77$ & 1,126 & ,266 &, 83 &, 000 \\
\hline İş yeterliliği & $111,24 \pm 18,78$ & $114,04 \pm 20,84$ & 1,669 & ,102 &, 83 &, 000 \\
\hline Sosyal zekâ & $65,04 \pm 13,43$ & $66,46 \pm 12,50$ & 1,561 & , 125 & ,88 & ,000 \\
\hline $\begin{array}{l}\text { Örgütsel } \\
\text { farkındalık }\end{array}$ & $139,68 \pm 17,34$ & $140,94 \pm 19,38$ & 902 & ,372 & ,86 & ,000 \\
\hline $\begin{array}{l}\text { Kişisel çalışma } \\
\text { özellikleri }\end{array}$ & $54,84 \pm 18,50$ & $53,66 \pm 19,13$ & 1,231 & ,224 & ,94 &, 000 \\
\hline
\end{tabular}

*t: Bağımlı gruplarda t testi: serbestlik derecesi: 49

** r: Pearson korelasyon analizi

Geçerlik, bir ölçme aracının ölçmeyi amaçladığı özelliği, başka herhangi bir özellikle karıştırmadan, doğru ölçebilme derecesidir. Özellikle yabancı kültürden uyarlanacak ölçeklerde ilk olarak dil ve kapsam geçerliği test edilmektedir. ${ }^{21,27} \mathrm{Bu}$ nedenle dil, kapsam, yap1 ve ölçüt geçerliğine bakılmaktadır.

Ölçek uyarlama çalışmalarının ilk basamağı, ölçeğin çevirisidir. Uyarlamanın psikometrik bölümünde, zaman alıcı ve karmaşı olan bu sürece özen gösterilmesi, ölçeğin geçerlik ve güvenirliği için büyük önem taşır. ${ }^{28}$ Ölçeğin dil geçerliğini sağlamak için çeşitli yöntemler kullanılmaktadır. $\mathrm{Bu}$ yöntemlerden en çok uygulanan grup çevirisi ve geri çeviri yöntemidir.
Geri çeviri yöntemi zaman alıcı olmasına karşın, ölçeğin kültürel eşitliğini sağlamak için dünyada en çok kullanılan yöntemdir. ${ }^{29}$ Orijinal ölçek İngilizce ve Türkçe bilen üç çevirmen tarafindan İngilizce'den Türkçe'ye çevrilmiştir. Düzeltmeler yapıldıktan sonra hemşirelik mesleğinde $0-3$ yıl arası çalışmakta olan hemşireler içinden 10 kişilik bir grup seçilmiş, çevirinin anlaşılırlı̆̆ 1 ve eşitliği konusunda bilgi alınmıştır. Anlaşılmayan kelimeler düzeltildikten sonra ölçekteki kelimelerin Türk toplumunda daha kolay anlaşılabilmesi için Eğitim Fakültesi Ölçme ve Değerlendirme biriminde olan hocalardan birinin ölçek maddeleri ile ilgili görüşü alınmış ve ölçeğin Türkçe formu oluşturulmuştur. Daha sonra orijinalinden hedef dile çevrilmiş olan ölçeğin tekrar orijinal dile geri çevrilmesi adımına geçilmiştir. Burada değişik eğitim 
düzeylerinde ve her iki dili de konuşabilen, ancak konu hakkında uzman olmayan 2 kişi ölçeği tekrar İngilizce'ye çevirmiştir. Orijinal İngilizce form ile geri çevirisi yapılan İngilizce form karşılaştırılmış, formların birbiriyle uyumlu olup olmadığına bakılarak, tek bir İngilizce form oluşturulmuştur. Sonrasında tıp ve hemşirelik mezunu olan Türkçe ve İngilizce bilen çoğunluğu idari birimlerde çalışan 30 kişilik bir gruba 15 gün arayla ölçeğin Türkçe ve İngilizce formu uygulanmıştır. Yapılan İngilizce ve Türkçe çeviri araştırmacı tarafından ölçeğin özgün hali ile karşılaştırılmış ve ölçeğin özgün formu ile örtüştüğü görülmüştür. Böylece ölçeğin dil geçerliği sağlanmıştır.

Ölçeğin kapsam geçerliğinde Kapsam Geçerlik İndeksi (KGI) değeri hesaplanmıştır. $\mathrm{Bu}$ tekniğin hesaplanmasında en az üç, en fazla yirmi uzman görüşü alınmasının uygun olduğu bildirilmektedir. ${ }^{21}$ KGİ .80 'den büyük ise ölçeğin madde kapsam geçerliği açısından yeterli olduğu savunulur. $^{29,30}$ Davis tarafından düşük KGI'ne sahip maddelerin ölçekten çıkartılması gerektiği belirtilmektedir. ${ }^{31}$ Araştırmada dokuz uzmanın görüşü alındıktan sonra hesaplanan KGİ değeri .95 olarak bulunmuştur. Ölçeğin KGİ değerinin kabul edilebilir düzeyde olması ölçeğin Türkçe formunun uzmanlar arasında ölçüm amacına uyduğu konusunda görüş birliğini yansıttığı şeklinde yorumlanmıştır.

Ölçekte yer alan maddelerin alt boyutu ile olan ilişkisini gösteren yol katsayılarının (faktör yükleri) en az .30 ve üzerinde olması önerilir. ${ }^{32,33}$ Ölçeğin Türkçe'ye uyarlama çalışmasında tüm maddelerin yol katsayıları (yükleri) .35 ile .89 arasında olmak üzere yeterli düzeyde bulunmuştur.

Doğrulayıcı faktör analizinde uyum iyiliği istatistiklerinin de istenilen düzeyde olması gerekir. Uyum istatistiği değerleri olarak adlandırılan değerler;

Ki-kare uyum istatistiği: Bir modelin kabul edilebilir olması için ki-kare değerinin anlamlı çıkmaması beklenir ki-kare değeri serbestlik derecesine bölünür ve çıkan değerin iki ya da altında olması modelin iyi bir model olduğunu, beş ya da daha altında olması modelin kabul edilebilir bir uyum iyiliğine sahip olduğunu gösterir. ${ }^{32,33}$ Ölçeğin Türkçe formunun doğrulayıcı faktör analizi sonuçlarına göre bu değer 3,85 olarak bulunmuş, bu değer modelin kabul edilebilir bir model olduğunu göstermiştir.

Sık kullanılan diğer uyum iyiliği testleri Root Mean Square Error of Approximation $($ RMSEA $=$ Tahminin Ortalama Karekök Hatası = Hataların Karekök Ortalaması), Standardized Root-mean-Square Residual (SRMR), Comparative Fit Index (CFI= Karşılaştırmalı Uyum Indeksi), Non-Normed Fit Index (NNFI), Goodness of Fit Index, (GFI= Uyum Iyiliği Indeksi), Adjusted Goodness of Fit Index (AGFI= Düzeltilmiş Uyum Iyiliği Indeksi)'dır. ${ }^{32,33}$

RMSEA'nın 0.08 'e eşit ya da küçük olması ve $p$ değerinin .05 'ten küçük olması (istatistiksel olarak anlamlı olması) uyumun iyi olduğunu ${ }^{33}, 0.10$ 'a eşit ya da büyük olması ise uyumun zayıf olduğunu gösterir. ${ }^{32} \mathrm{Bu}$ çalışmada RMSEA değerinin anlamlı ve .087 bulunması $(\mathrm{p}<.001)$ faktör yapısı için uyumun olduğunu göstermiştir.

SRMR'nin .10'dan küçük olmasis ${ }^{33}$, CFI, NNFI değerlerinin .90'a eşit ya da üstünde olması uyumun olduğunu gösterir. .90 ve üstü kabul edilebilir uyum .95 ve üzeri iyi bir uyumun göstergesidir. ${ }^{32} \mathrm{Bu}$ çalışmada elde edilen SRMR (.064), CFI (.97), NNFI (.97) değerlerine göre Yeni Mezun Hemşirelerde İşe Hazır Olma Ölçeği'nin Türkçe formunun uyumunun iyi olduğu görülmüştür.

AGFI'nin 0.80'e eşit ya da üstünde olması uyumun olduğunu gösterir. GFI değerinin $.85^{\prime} \mathrm{e}$ eşit ya da üstünde olması uyumun olduğunu gösterir. ${ }^{34} \mathrm{Bu}$ çalışmada elde edilen GFİ (.70) ve AGFİ (.67) değerlerinin yeterli uyum değerine sahip olmadığ 1 ancak uyum değerine yaklaştığı görülmüştür.

Ölçüt geçerliği elde edilen puanların bir ölçekte ölçülmek istenen özelliğe sahip olanlarla olmayanları, ölçülen özellik boyutunda birbirinden ayırt edebilmedir. ${ }^{30}$ Hemşirelerin yeni mezun hemşirelerde işe hazır olma ölçeğinden aldıkları puanlar ile eş zamanlı kullanılarak elde edilen "kendinizi işinize ne kadar hazır hissediyorsunuz" 
içinde bulunan maddelerin iç tutarlığının bir

sorusundan elde edilen puanlar arasında pozitif yönde, güçlü ve istatistiksel olarak ileri düzeyde anlamlı bir ilişkinin olduğu belirlenmiştir $(\mathrm{r}=.61, \mathrm{p}=.000)$.

Güvenirlik bir ölçüm aracının aynı koşullarda tekrarlanan ölçümlerde birbiriyle tutarlı ve kararlı ölçme sonuçları vermesidir. ${ }^{21,30,35}$ Bir ölçüm aracının güvenirliğinin belirlenmesinde yaygın olarak test-tekrar test, paralel form güvenirliği, bağımsız gözlemciler arası güvenirlik ve iç tutarlılık yöntemleri kullanılmaktadır. ${ }^{21}$ Güvenirliğin belirlenmesinde birçok yöntem bulunmasina rağmen, hangisinin kullanılacağı madde puanlarının doğasına, toplanacak veri türüne, araştırma problemine, araştırma koşullarına, araştırma amaçlarına ve yanıtlardaki olası objektifliğe göre bir veya birden fazla güvenirlik yöntemi kullanılabilmektedir. ${ }^{30,36}$ Ölçeğin güvenirliğinin belirlenmesinde madde analizi, iç tutarl1l1k ve test- tekrar test yöntemleri kullanılmıştır.

Madde korelasyon analizi, ölçüm aracının maddeleri ile ölçek toplamı arasındaki ilişkilinin bulunmasında kullanılan bir yöntemdir. Her madde ile ölçek toplam puanı arasındaki korelasyonları pearson momentler çarpımı yöntemiyle hesaplanır. Madde analizlerinde pearson korelasyon katsayisı değerleri; 0-.25 (çok zayıf), .26-.49 (zayıf), .50-.69 (orta), .70-.89 (yüksek), .90-1.00 (çok yüksek) olarak değerlendirilmektedir. ${ }^{20}$ Maddeler aras1 korelasyon analizinde korelasyon katsayısının işareti negatif, değeri sifir veya sifira yakın ise bu durum, maddenin diğer maddelerle ölçülmek istenen tutumu ölçmede yetersiz olduğunu gösterir. Maddelerin birbirleriyle ve ölçek puanlarıyla yüksek korelasyona sahip olmaları aynı boyutta ölçüm yaptıklarını göstermektedir. ${ }^{30}$ Ölçeğin alt boyutlarının toplam ölçek puanıyla korelasyonları incelendiğinde, güvenirlik katsayıları $r=.54$ ile .85 olarak saptanmıştır. Pozitif yönde ve istatistiksel olarak ileri düzeyde anlamlı olduğu bulunmuştur $(\mathrm{p}<.001)$.

Likert tipi ölçeklerde iç tutarlılığın belirlenmesinde yaygın olarak kullanılan Cronbach Alfa Güvenirlik katsayısı, ölçek ölçüsüdür. ${ }^{21,30}$ Birbiriyle yüksek ilișki gösteren maddelerden oluşan ölçeklerin $\alpha$ katsayısının yüksek olması beklenmektedir. ${ }^{30}$ Cronbach alfa katsayıs1 $.00<\alpha<.40$ ise ölçek güvenilir değil, . $40<\alpha<.60$ ise düşük düzeyde güvenirlik, . . $60<\alpha<.80$ ise ölçek oldukça güvenilir, $.80<\alpha<1.00$ ise ölçek yükssek düzeyde güvenilir şeklinde değerlendirilmektedir. ${ }^{20,21}$ İç tutarlık katsayısı için genel kabul edilen görüş bu katsayının en az .70 düzeyinde olmasıdır. ${ }^{21}$ Ölçeğin iç tutarlık analiz sonuçlarına göre, tüm ölçeğin Cronbach alfa güvenirlik katsayısı .94 olarak bulunmuştur. Ölçeğin alt boyutlarının Cronbach alfa güvenirlik katsayısı; iş yeterliği ve sosyal zekâ alt boyutunda .91, örgütsel farkındalık alt boyutunda .93 , kişisel çalışma özellikleri alt boyutunda .88 olarak bulunmuştur. $\mathrm{Bu}$ çalışmaya göre ölçeğin orjinal hali ile Türkçe'ye uyarlanmış son durumunun uyumlu olduğu görülmüştür.

Araştırmamızda zamana karşı değişmezliğini belirlemek amacıyla ölçek test tekrar test yöntemi ile değerlendirilmiştir. Dil çevirisi ve kapsam geçerliliği süreçlerinin tamamlanmasının ardından elde edilen Türkçe ölçek, 50 hemşireye 15 gün sonra tekrar uygulanarak arasındaki fark bağımlı gruplarda t testi (= iki eş arasındaki farkın önemlilik testi) ile değerlendirilmiştir. Ölçeğin zamana göre değişmezliği çalışmaya katılan ilk 50 hemşireye iki hafta ara ile yapılan ikinci ölçümden elde edilen puan ortalamaları arasındaki fark bağımlı gruplarda t testi (= iki eş arasındaki farkın önemlilik testi) ile değerlendirilmiştir. Hem toplam ölçeğin hem de dört alt boyutun tekrarlayan iki ölçümden elde edilen puan ortalaması arasinda anlamlı düzeyde fark olmadığı saptanmıştır ( $\mathrm{p}>.05)$.

Ölçeğin ve dört alt boyutunun test-tekrar test puanları arasındaki ilişki pearson korelasyon analizi ile incelendiğinde hem toplam ölçek hem de dört alt boyutun ilk ve ikinci ölçümden elde edilen puanları arasında çok güçlü $(r=.83$ ile .94 arasında), pozitif yönde ve istatistiksel olarak ileri düzeyde 
anlamlı bir ilişki olduğu saptanmıştır $\quad(\mathrm{p}<.001)$.

\section{SONUÇ VE ÖNERIILER}

Yeni mezun hemșirelerde işe hazır olma ölçeği Türk toplumuna uygulanabilir geçerli ve güvenilir bir ölçektir. Cronbach alfa katsayıları ölçeğin toplamı ve alt boyutlarında yeterli düzeyde bulunmuştur.

Araştırmada ölçek maddelerinin ölçek toplam puanı ile korelasyon katsayıları değerlerinin çok iyi düzeyde ayırt edici ve güvenilir olduğu belirlenmiştir. Ölçeğin testtekrar test analizine ilişkin korelasyon değeri ölçeğin zamana göre değişmezliğinin yüksek düzeyde olduğu, ölçeğin zaman karşısında etkilenmediğini göstermektedir.
Geçerli ve güvenilir olduğu kanıtlanan ölçek Türk toplumunda yeni mezun hemşirelerin işe hazır olma düzeyinin belirlenmesi, geliştirilmesi ve değişim sürecinin başlatılmasına yönelik yapılacak çalışmalarda kullanılabilir.

Ölçeğin puanı arttıkça işe hazır oluşluğun artıyor olarak değerlendirilmesi, araștırmacılar açısından kolay puanlanması, karmaşı skorlama algoritmalarının olmaması, uygulanmasının kolay olduğunu düşündürmektedir. Hemșirelikte daha büyük örneklem grupları ile geçerlik ve güvenirliğinin tekrarlanması önerilebilir.

\section{KAYNAKLAR}

1. Domino, E. (2005). "Nurses Are What Nurses Do-Are You Where You Want To Be?" AORN Journal, 81(1), 187-198. doi: 10.1016/S0001-2092(06)60071-9.

2. Fletcher, K. (2007). "Image: Changing How Women Nurses Think About Themselves. Literature Review". J Adv Nurs, 58(3), 207-215. doi: 10.1111/j.1365-2648.2007.04285.x

3. Heung, Y.Y.J, Frances Wonng, K.Y, Enid Kwong, W.Y, Tany, To, S.S. and Daniel Wong, H.C. (2005). "Severe Acute Respiratory Syndrome Outbreak Promotes A Strong Sense of Professional İdentity among Nursing Students". Nurse Education Today, 25(2), 112-8. doi: 10.1016/j.nedt.2004.11.003

4. Scott E.S, Engelke, M.K. and Swanson, M. (2008). "New Graduate Nurse Transition: Necessary or Nice". Applied Nursing Research, 21, 75-83.

5. Walker, A, Yong, M, Pang, L, Fullarton, C, Costa, B. and Dunning, T. (2013). "Work Readiness of Graduate Health Professionals". Nurse Education Today, 33(2), 116-122. doi: 10.1016/j.nedt.2012.01.007

6. Walker, A, Storey, K, Costa, B. and Leung, R. (2015) "Refinement and validation of the Work readiness scale for graduate nurses". Nursing Outlook. 63(6), 632-638. doi: 10.1016/j.outlook.2015.06.001

7. Walker, A. and Campbell, K. (2013). "Work Readiness of Graduate Nurses and The İmpact on Job Satisfaction, Work Engagement and Intention To Remain". Nurse Education Today, 33(12), 1490-1495. doi: 10.1016/j.nedt.2013.05.008

8. Cavanagh, J, Burston, M, Southcombe, A. and Bartram, T. (2015). "Contributing to a Graduate-Centred Understanding of Work Readiness: An Exploratory Study of Australian Undergraduate Students' Perceptions of Their Employability". The International Journal of Management Education, 13(3), 278-288. doi: 10.1016/j.ijme.2015.07.002
9. Caballero, C. and Walker, A. (2010). "Work Readiness in Graduate Recruitment and Selection: A Review of Current Assessment Methods". Journal of Teaching and Learning for Graduate Employability, 1(1), 13-25. doi: 10.21153/jtlge2010 vol1nolart 546

10. Kramer, M. (1974). Realityshock: Why Nurses Leave Nursing St. Louis, MO: Mosby.

11. Duchscher, J.E.B. (2009). "Transition Shock: The İnitia Stage of Role Adaptation for Newly Graduated Registered Nurses". Journal of Advanced Nursing, 65(5), 1103-1113. doi:10.1111/ j.1365-2648.2008.04898.x

12. Halfer, D. and Graf, E. (2006). "Graduate Nurse Perceptions of The Work Experience". Nursing Economics, 24(3), 150155 .

13. Hickey, M.T. (2010). "Baccalaureate Nursing Graduates' Perceptions of Their Clinical Instructional Experiences and Preparation for Practice". Journal of Professional Nursing, 26(1), 35-41. doi: 10.1016/j.profnurs.2009.03.001

14. Wolff, A.C, Pesut, B. and Regan, S. (2010). "New Graduate Nurse Practice Readiness: Perspectives on The Context Shaping Our Understanding and Expectations". Nurse Education Today, 30, 187-191. doi: 10.1016/j.nedt.2009.07.011

15. Hillman, L. and Foster, R.R. (2011). "The İmpact of Nursing Transitions Programme on Retention and Cost Savings". Journal of Nursing Management, 19 (1), 50-56. doi:10.1111/j.1365-2834.2010.01187.x

16. Maben, J, Latter, S. and Clark, J.M. (2006). "The TheoryPractice Gap: İmpact of Professional-Bureaucratic Work Conflict on Newly- Qualified Nurses". Journal of Advanced Nursing, 55(4), 465-477. doi: 10.1111/j.1365-2648.2006.039 $39 x$ 
17. Parker, V, Giles, M, Lantry, G. and McMillan, M. (2014). "New Graduate Nurses' Experiences in Their First Year of Practice". Nurse Education Today, 34(1), 150-156. doi: 10.1016/j.nedt.2012.07.003

18. Scott, E.M. (2005). The Transition of New Graduate Nurses into The Workplace. Doctor of Philosophy in Nursing Dissertation,

19. Polit, D.F. (1996). Data Analysis - Statistics For Nursing Research. Appleton - Lange: Connecticut, s.317-324

20. Akgül, A. (2003). Tıbbi Araştırmalarda İstatistik Analiz Teknikleri. Ankara: Emek Ofset Ltd.Şti., s.440-446.

21. Tavşancıl, E. (2014). Tutumların Ölçülmesi ve SPSS İle Veri Analizi. Ankara: Nobel Yayıncılık.

22. Caballero, C.L. and Walker, A. (2011). "Fuller-Tyszkiewicz M. The Work Readiness Scale (WRS): Developing A Measure To Assess Work Readiness in College Graduates". Journal of Teaching and Learning for Graduate Employability. 2, 41- 54

23. Fukada, M. (2018). "Nursing Competency: Definition, Structure and Development". Yonago Acta Med, 61(1), 1-7. doi: 10.33160 / yam.2018.03.001

24. Thorndike, E.L. (1920). “Intelligence and Its Use”. Harper's Magazine, 140, 227-235.

25. Tolbert, P.S. and Hall, R. (2009). Organizations: Structures, Processes and Outcomes (10th ed.). Boston; MA: Pearson Education.

26. https://www.greatvaluecolleges.net/lists/5-strengthsnecessary-for-success-in-the-nursing-profession/ Great Value Colleges; 5 Strengths Necessary for Success in the Nursing Profession.13/12/2020
27. Tekindal, S. (2017) (Ed.) Eğitimde Ölçme ve Değerlendirme. Ankara: Pegem Akademi.

28. Gözüm, S. ve Aksayan, S. (2003). "Kültürlerarası Ölçek Uyarlaması İçin Rehber II: Psikometrik Özellikler ve Kültürlerarası Karşılaştırma". Hemşirelikte Araştırma Geliştirme Dergisi, 5(1), 3-14.

29. Aksayan, S. ve Gözüm, S. (2002). "Kültürlerarası Ölçek Uyarlaması İçin Rehber I: Ölçek Uyarlama Aşamaları ve Dil Uyarlaması". Hemşirelikte Araştırma Dergisi, 4 (1), 9-14.

30. Tezbaşaran, A. (2008). Likert Tipi Ölçek Hazırlama K1lavuzu. Üçüncü Sürüm E-Kitap, http://www.academia. https://www.academiaedu/1288035/Likert Tipi Ölçek Hazır lama_Kilavuzu. 07.02.2017

31. Şimşek, Ö.F. (2007). Yapısal Eşitlik Modellemesine Giriş Temel İlkeler ve LISREL Uygulamaları. Ankara: Cem Web Ofset.

32. Harrington, D. (2009). Confirmatory Factor Analysis. Oxford University Press. Newyork, USA

33. Davis, L.L. (1992). "Instrument Review: Getting The Most From A Panel of Experts". Applied Nursing Research 5, 194 197

34. Cokluk, Ö, Şekercioğlu, G. ve Büyüköztürk, S.. (2009). Sosyal Bilimler İçin Çok Değişkenli İstatistik SPSS ve Lisrel Uygulamaları. Ankara: Pegem Akademi.

35. Ercan, İ. ve Kan, İ. (2004). "Ölçeklerde Güvenirlik ve Geçerlik". Uludağ Üniversitesi Tıp Fakültesi Dergisi 30, 211 216.

36. Aker, S, Dündar, C. ve Pekșen, Y. (2005). "Ölçme Araçlarında İki Yaşamsal Kavram: Geçerlik ve Güvenirlik". O.M.Ü. Tıp Dergisi 22, 50-60. 